\title{
The end is now: Augustine on History and Eschatology
}

\begin{abstract}
Author:
Johannes van Oort ${ }^{1,2}$

Affiliations:

${ }^{1}$ Radboud University

Nijmegen, The Netherlands

${ }^{2}$ Faculty of Theology,

University of Pretoria,

South Africa

Note:

Prof. Dr Johannes van Oort is Professor Extraordinarius in the Department of Church History and Church Polity of the Faculty of Theology at the University of Pretoria, South Africa.

\section{Correspondence to:}

Hans van Oort

Email:

j.van.oort@planet.nl

Postal address:

Van Renesselaan 24, $3703 \mathrm{AH}$

ZEIST, The Netherlands

Dates:

Received: 19 Oct. 2011

Accepted: 05 Feb. 2012

Published: 04 May 2012

How to cite this article: Van Oort, J., 2012, 'The end is now: Augustine on History and Eschatology', HTS Teologiese Studies/ Theological Studies 68(1), Art. \#1188, 7 pages. http:// dx.doi.org/10.4102/hts. v68i1.1188
\end{abstract}

C 2012. The Authors. Licensee: AOSIS OpenJournals. This work is licensed under the Creative Commons Attribution License.
This article dealt with the church father Augustine's view on history and eschatology. After analysing the relevant material (especially his City of God and the correspondence with a certain Hesyschius) it was concluded that, firstly, Augustine was no historian in the usual sense of the word; secondly, his concept of historia sacra was the heuristic foundation for his idea of history; thirdly, the present is not to be described in the terms of historia sacra, which implies that he took great care when pointing out any instances of 'God's hand in history'; fourthly, the end times have already started, with the advent of Jesus Christ; fifthly, because of the uniqueness of Christ's coming, it runs counter to any cyclical worldview; sixthly, identifying any exact moment of the end of times is humanly impossible and seventhly, there is no room for any 'chiliastic' expectation.

\section{Preamble}

Why should the church father Augustine figure in a Festschrift for an Old Testament scholar? I am sure Prof. Pieter M. Venter will be aware of the answer, because both in his scientific research and in his outlook as a Reformed theologian, he knows about the church father's main concerns. In actual fact, Augustine is at the background of typical reformed theologoumena, such as justification and grace, and predestination and perseverance. But apart from this fairly common knowledge of the close relationship between Augustine's and Reformed theology, there is another important point, which is that Augustine and Reformed theology share a similar view on history in general and the history of salvation in particular (see e.g. Berger 1955; Smits 1956-58). It is this typical feature, however, which clearly has Old Testament texts and concepts as its ultimate foundation! Although the focus of the present study is on Augustine himself, and biblical sources will be mentioned only in passing, to the attentive reader it will be clear how extensively Augustine was nourished from Old Testament sources. Reading Augustine on history and eschatology is, to a large degree, reading certain trends of historiography in Israel itself, trends which have been studied by such eminent Old Testament scholars as Gerhard von Rad and Martin Noth (see e.g. Von Rad 1958:189-204, 1974:175-190, 191-212; Noth 1991). Reading this study, it may be hoped, will enrich students of both the Old Testament and Patristics, and assist them to realise their common sources and mutual interests.

\section{Introduction}

Augustine's concept of history and eschatology is part of a specific context. One cannot understand his ideas when they are not approached from this wider setting. In particular, his view on the end of time and the last things (the eschata) is fully intertwined with his idea of history in general.

The whole subject of Augustine's concept of history and, for instance, its closely related theory of time, is in fact a 'mer à boire'. Whoever undertakes to give an overview of this in only a few pages, is reminded of the famous story of the theologising Augustine walking along the shore of the immeasurable sea (Marrou 1954-55:131-135). ${ }^{1}$ There are many publications on 'Augustine and history', his concept of time, and much has also been said about Augustine as an 'eschatological' thinker. I only refer here to the one-time famed book of Wilhelm Kamlah $(1940,1951)$ in which he gave an 'eschatological' interpretation of Augustine in line with Martin Heidegger and Rudolf Bultmann. Many of these studies originally appeared at certain watershed moments in modern history, such as in the crises experienced in and around the two World Wars, but also at the start of the twenty first century.

Several new studies of Augustine's theory of history, time and the future were published about one decade ago, and in many instances these studies were induced by the imminent turn of the

1.This well-known legend, depicted by, amongst others, the Flemish Barocque painter Peter Paul Rubens, tells that Augustine, when walking along the seashore during the time he wrote his De Trinitate, met a child trying to empty the ocean with a bucket. As he stood in wonder at what was happening, the child (in reality an angel; or even Christ) answered that his act would have a better chance of success than Augustine's attempt to explain the immeasurable mystery of the Trinity. 
millennium, (see e.g. Müller 1993; Trompf 2000, esp. ch. VII; O'Daly 1999; Horn 1997). ${ }^{2}$ Most of them are inspired by his work De civitate Dei, the pivotal writing which shall be focussed on here. In view of new speculations on the end of the world on December 21, 2012, which is said to be the enddate of the 5.125-year-long cycle of the Mayan Long Count Calendar, ${ }^{3}$ a renewed orientation on this work seems to be worthwhile to establish a balanced Christian view. It is in his work On the City of God, composed in the years 412-426/7, that the African church father unfolded his views, which by then had come to full maturity, in a systematic manner. But other writings, such as his Confessions and several of his sermons and letters, also contain important material. When it is appropriate, this 'additional' material will be adduced as well. ${ }^{4}$

\section{What is history?}

It has been frequently and rightly argued that Augustine was the first to unfold both a Christian inspired and, at the same time, comprehensive view of history (see e.g. Löwith 1949; Horn 1997:179-181; Van Oort 1991: esp. 93-102; Schwarte 1966; Wachtel 1960). In his work De civitate Dei he wrote, in particular, on the questions of what history is, how we consider its meaning and, moreover, he expounded his understanding of eternity, time, and eschatology.

Whether Augustine himself should be seen as a full-fledged historian in the modern sense, however, is questionable. Still, his research of sources is sometimes quite methodical, for example in regard to the Donatist controversy and for the historical sections of his De civitate Dei. In the first instance he delved into archives in Carthage to look for the origins and early developments of the Donatist schism. The results of these investigations are reported in his Synopsis of the Conference with the Donatists of the year 411, a report in which he gives an overview of the acts of the great and decisive conference of that year in an expert (though sometimes tendentious) manner (see e.g. Lancel 1992:681-684; Weidmann 1998: esp. 9-10). In regard to the historical sections in De ciuitate Dei, Othmar Perler $(1969: 315,424)$ has convincingly argued that Augustine researched the libraries and archives of Carthage in the winter of 412-413 (see also Altaner 1967:174-180; Monceaux 1923:243ff.). From that time onwards, there is a sudden increase of testimonia from pagan authors, such as the historians Titus Livius, Publius Annius Florus, Junianus Justinus, and the famous Sallustius and Varro. This fact can only be explained by Augustine's renewed or, in some cases, even very first study of these sources (Hagendahl 1967:705 et alibi).

Yet, Augustine is neither a historian in the modern sense of the word, nor a historian in the classical sense. Even if he

2.See also the special 1999 issue of Augustinian Studies (vol. 30, nr. 2).

3.Presently (latest access 17 October 2011) the internet is overflowing with discussions and speculations on this item and, in the meantime, more serious media, such as The Washington Post, The New York Times Magazine, The Guardian, Le Monde and Pravda, have published articles on the ' 2012 phenomenon' as well.

4. Abbreviations used in this article are as follows: $\mathrm{A}$. = Augustine; $B A=$ Bibliothèque Augustinienne, Paris 1949-present; $D C D=$ De civitate Dei, 4th edn. by B. Dombart \& A. Kalb, reprinted in BA 33-36; Conf. = Confessiones; ep. = epistola; $s .=$ sermo. Other abbreviations and abbreviations of A.'s works are in accordance with common practice. did research original sources, his description of the material, whilst being mainly an enumeration of events, is mostly without reference to its historical context. In point of fact, Augustine did not wish to be a historian in the mould of the pagan historical writers, and even held a rather dismissive view of their profession: '... if I would try to tell it or even summarize it, I as well would not be more than a historian ...' (DCD III, 18). ${ }^{5} \mathrm{He}$ always rendered, and thus tried to explain, facts from the past within his own Christian theological framework.

Before we examine his Christian frame of reference more closely, it is important to note Augustine's use of terminology. He speaks of 'sacred history' (historia sacra) and thus also, by implication, of non-sacred or secular history (see Müller 1993:229-232). Although he did not use possible designations such as historia saecularis or historia profana for the latter, these terms are applicable (Markus 1970:1-21). ${ }^{6}$ Historia is the story, the rendering of the events, and sacra, for Augustine, means that these events are documented in the Christian Scriptures, which were written under divine inspiration and therefore they are normative. Whatever falls outside of that historia sacra, that is the wide range of events not recorded in the Old and New Testaments, belongs to 'profane' history. Hence, all history not written under divine inspiration, including the history of the church after the New Testament, is considered to be 'profane' history.

This view implies that, for Augustine, on the map of sacred history the present is a blank spot, and we, normal human beings, are not able to explain the current world events and even the events of church history in terms of historia sacra. Or, to put it differently, we are not able to point out 'God's hand' in history exactly and unanimously. When the biblical prophets (i.e. the prophetically written biblical writings) are silent about it, we have to keep silence as well (see Markus 1970:159). What we do know, on the basis of biblical-prophetic inspiration, are the articuli temporum of world history (see e.g. De cat. rud. 5 and 10). These 'main points of history' are unambiguously clear in the so-called 'ages of the world' (aetates mundi) that run from Creation to Judgement Day.

\section{The course of history according to 'The City of God'}

The exposition of the history of salvation, or Heilsgeschichte in the classical sense, is nowhere handled more extensively by Augustine than in his great work, The City of God, which he composed in the years 413-426/7 (see Cullmann 1946,

5.'Si enarrare vel commemorare conemur, nihil aliud quam scriptores etiam nos erimus historiae'. In other instances (e.g. De docr. chr. II, 28,42-44) A. seems to attach value to 'normal' history writing as a help to theological exegesis. There is appreciation for the cognitio historalis in $D C D$ X, 32 and occasionally here the (story of) history is called upon as witness to the truth: 'historia testatur', 'indicat', 'probat'; cf. DCD XV, 5; XX 8 and, for example, C. Faustum XIII,7. Yet it should be about facts, and not about fables and fantasies which are considered to be common amongst the profane historians.

6.Markus' explanation of historia sacra and historia profana seems to be sound but one should seriously doubt (and even contradict) his use of the concept of saeculum (see Van Oort 1991:152-153). My analysis and critique of Markus' saeculum (see Van Oort 1991:152-153). My analysis and critique of Markus
concept of saeculum is now accepted by, amongst others, Horn (1997:13) and O’Daly (1999:154) 
1965; Löwith 1949:passim). We shall not delve into the inception history, nor his reason for writing this great work, namely, it is, in short, an apologetic-catechetical writing and - with regard to its full title given in the best manuscripts foremostly directed adversus paganos. These pagan opponents are not merely to be countered, however, but are also to be positively instructed. In the allegory of the two civitates, metaphorically named as Jerusalem and Babylon, Augustine tells his tale of church and world history. This narratio must convince (probare) and bend (flectere), and the historical process must be assessed by pagans and Christians alike, according to the antithesis between the civitas Dei and the terrena civitas.

It is within this framework that Augustine, in particular in the second part of The City of God, describes the significance of all events and how the narration of history is to be arranged. Of most importance in this context is his search for the transcendental basis and meaning of the past, the present and the future. In doing so, Augustine perceives history divided into six periods (aetates):
the first is from Adam until the Flood (Noah)
the second, from Noah to Abraham
the third, from Abraham to David
the fourth, from David to the Babylonian Captivity
the fifth, from the Captivity to Christ
lastly, the period from Christ until the end of the world (e.g. DCD XXII, 30). ${ }^{7}$

On this sixth period of indefinite length, the preceding aetates were aimed. Here already we observe Augustine's view, that the centre of history is the incarnation of Jesus Christ. Christ's incarnation is the truly new event in history, and from this pivotal event history receives its meaning. In combination with the church's doctrine of the Creation and its fulfilment in Christ's parousia, the incarnation of Christ is the guiding factor in all historical events. In actual fact, all historical events are emanating from and returning to God.

In The City of God, Augustine arranges his subject matter into three times four books. Books XI-XIV are about the (in essence supra-worldly and supra-timely) origin of the two civitates. The earthly, and therefore temporal course of both 'cities', is covered in books XV-XVIII. Augustine's eschatological perspective comes to full expression in the last four books. They, firstly, deal with the end destination of both cities, namely, the greatest good (summum bonum) and eternal peace (pax) which has its absolute antithesis in the greatest evil (XIX). Secondly, they deal with the last judgement (XX), and the eternal punishment of the damned (XXI) and thirdly and finally, with the heavenly joy of the righteous (XXII).

When the composition of The City of God is taken into account, the actual interest of Augustine is not difficult to determine. He is dealing twice as much with the origin (exortus) and end-goal (or 'destined ends', debiti fines) of

7.A. compares the six periods with the six days of creation (see e.g. C. Faustum XII, 8 and esp. De Gen. c. Man. I, 35-41).

8.For A., the first meaning of civitas is 'city' or 'city-state' (cf. the classical Greek concept of polis). both cities than with their earthly history. It is not the progress (procursus, excursus) of history that is in the centre of Augustine's attention, but its meaning. Even though he describes the earthly history in detail, and divides it into six periods after the six days of Creation and the six periods in human life (e.g. DCD XVI, 43), ${ }^{9}$ these temporal events are not his main interest. Augustine's real interest is the philosophy (or rather, the theology) of history (cf. Wachtel 1960:7-14, esp. 8). We cannot call him a philosopher of history such as the medieval prophet Joachim of Fiore or the nineteenth century thinker Karl Marx, who on the basis of teleological tendencies came to historical prognoses. But Augustine is surely a philosopher of history due to his knowledge of its origin and progression, and in his acute sense of history's uniqueness. His exposition, in The City of God, is witness to a real historical-philosophical view, namely that historical facts are dealt with indeed (although, in actual fact, only partly and selectively); and most important, in this exposition, is the interpretative framework of his theological design.

\section{Time and eternity}

Before we take a closer look at the especially eschatologically determined frame of Augustine's view of history, it is instructive to pay attention to his concept of 'time'. As is well known, Augustine has said many insightful things about time, not least in the last three books of his Confessions (see O'Daly 1977:265-271, 1986:159-164; Schmidt 1985; Meijering 1979). Here, in his exposition of the biblical Creation story, ${ }^{10}$ he focuses anew on the problem of time. Augustine discusses the relationship between God and man, Creator and creature, within the concept of the relationship between eternity and time. God, as creator of the world, is simultaneously the One who created time, yet he is not subjected to time. God's being is eternal. Eternity does not mean endless being, but rather points to the Greek philosophical concept of timeless being. In God there is no contradiction between time and eternity. God's eternity is before all time, exists in all time and extends beyond all time. 'You created all times, and You exist before all times, and there was never a time when time did not exist' (Conf. XI, 13, 16). ${ }^{11}$ God spans all time and is exalted far above time.

The state of being of the created world and its history is characterised by time. Time is one with creation, and time is linked with changeability. But what is time? It seems immeasurable, because the future is not here yet, the past has already gone by, and the present is so fleeting that it is incomprehensible. Yet we speak of present, past, and future. The present we observe as it goes by, the past we know and measure through memory, and the future through expectation. Time exists only in the human mind, it is a distentio animi, and can be measured only in and by the human intellect.

9.The distinction of infantia, pueritia, adolescentia, iuventus, gravitas, senectus.

10.The third attempt, after De Gen. c. Man. and De Gen. ad litt. liber imp. After this one he made one further attempt in De Gen. ad litt. libri XII.

11.'Omnia tempora tu fecisti et ante omnia tempora tu es, nec aliquo tempore non erat tempus'. 
Without Creation there is no time, and without time there is no history. Apart from being a philosopher who thought along the lines of the current wisdom traditions, ${ }^{12}$ Augustine was also a biblical theologian. He knew that, according to the Bible, God's plan in Creation is a plan for salvation. That plan of salvation is the actual subject of his attention. It is principally on these grounds that Augustine may be characterised as an eschatological thinker, and, thus, the 'end times' are central in his thoughts.

\section{The end times as present and future}

As (increasingly) a biblical theologian on the one hand and (decreasingly, but still remaining in essence) a neo-Platonic thinker on the other hand, Augustine always saw history from a double perspective. It makes him fascinating, but, at the same time, brings a certain ambivalence to his thinking (Marrou 1950).

Concepts of the neo-Platonic world view always remained valid for Augustine. A permanent element in his thought is the fundamental distinction between the changeable and the unchangeable, time and eternity, humankind subjected to change and the unchangeable God. The eternal order of being transcends any earthly being. Seen in this way, history is only negative, as it is the mode of being of this world. Thus, without Creation and its subsequent Fall, there would have been neither time nor history (cf. e.g. Williams 1999:251-254; Quinn 1999:133-164).

Over and against (and, increasingly, over and above) this world view Augustine read in his Bible that God's plan of creation is simultaneously a plan for salvation. The created world is arranged in the order of time to realise this plan of salvation. It is within the frame of history that the return of the fallen creature to God occurs. ${ }^{13}$ Augustine even states that God's plan for salvation is eternal and already includes the Fall and God's project of salvation. Thus, what is happening now is simply a temporal unfolding of a pre-temporal concept.

Whether Augustine, in this so-called supralapsarian view, is in line with the apostle Paul and other biblical authors may remain here an unanswered question. We can take for certain, however, that the church father had a number of New Testament and other early Christian traditions on his side when he outlined the place of Christ in all of his theological enquiries. For Augustine, Jesus Christ is the bringer of salvation, as the Mediator between God and men (mediator Dei et hominum) (cf. e.g. DCD IX, 15; X, 20; $X I, 2)$. He entered time and even took the temporal manner of human existence. The same Christ, who is the principle of the universe (e.g. Conf. X, 67-70), became man: 'Christ became man in time, $(\mathrm{He})$ through whom time was created'

12. Which philosophical traditions these were is a question difficult to ascertain and is still an issue of much debate (see e.g. O'Daly 1999:257-259).

13.For A. it seems to be only fallen angels and humans; from an anti-Manichaean sentiment Roman 8 (about 'the groaning of the creation') is explained as referring solely to rational creatures, that is humans and angels (see e.g. Clarke 1958:133-164).
(Ioh. Ev. 23, 12). According to this concept, too, time first of all has a negative connotation. Augustine's Christmas sermons often express that Christ came to free us from ... time. 'Our humble Creator came, a creature among us (...). God before time, human being in time, to free men from time' (S. Guelf. 32, 5; cf. e.g. s. 187, 4; see Wachtel 1960:46). Christ's incarnation has a far-reaching significance without which there could be no salvation history. The sixth and last world period (aetas mundi) has started now, and just as man was created on the sixth day, so the sixth period was ushered in by the advent of the second Adam. In this world aetas the new man, appeared, in the last eschatological period in which radical regeneration takes place.

For Augustine, the end times were heralded with this definitive event. Therefore, the end times are already present now, from Christ's incarnation until his glorious return. In book XII of The City of God, in particular, he points out that, because of Christ's advent, 'something new happened in time.' The pivotal idea is expressed in only five Latin words: fit aliquid novi in tempore (DCD XII, 14). This section of the book deals with 'the sages of this world' who teach the circular progression (circuitus) of coming and going eras. Such a view implies that everything returns. But does such a world view bestow any real happiness? Blessedness, which is true happines (vera beatitudo), can only be real whilst being definitive, 'When the soul comes to happiness without ever returning to wretchedness, then there originates something new in time which has no end in time' (DCD XII, 13). ${ }^{14}$ Augustine poses the question, whether the same holds for the world and man created in this world, and mentions that the 'false cycles' (falsi circuitus) are to be avoided by walking on the right path (trames recti itineris) of 'the sane (i.e. the Christian) doctrine'. Further on he argues against the circular thinking of philosophers (and theologians ${ }^{15}$ ) by pointing out that right path. 'Far be it, I say, that we believe such accounts. For once for all did Christ die for our sins' (DCD XII, 14$).{ }^{16}$

In the context of Augustine's view on history, the expression 'once for all' (semel) has a distinctive sound. It refers to the New Testament's 'once for all' (evfa,pax) in the writings of the apostle Paul and others (see e.g. Stählin 1933:382-383; cf. Cullmann 1946:107-108). In God's salvation history there occurred a unique, definitive and decisive event. Elsewhere Augustine also emphasises the singularity of the Christ event (cf. e.g. Trin. XV, 27, 49). This event was a definitive novum, and through it humankind's salvation and regeneration comes into being. When, in accordance with Roman historiography, Augustine calls the last period of history 'the world's old age' (senectus mundi) (e.g. ep. 199, 1), this term has a positive meaning. The senectus mundi not only denotes decline, but also regeneration. In this period 'the inner man is renewed day by day' (e.g. De Gen.c. Man. I, 40; De div. quaest., qu. 58, 2; cf. 2 Cor 4:16).

14.At si ad miserias numquam ulterius reditura ex his ad beatitudinem pergit [sc anima]: fit ergo aliquid novi in tempore, quod finem non habet temporis'.

15.Such as Origen. It is important to see that cyclical theories are criticised by A. partly with reference to Porphyry (see DCD XII, 21).

16.'Absit, inquam, ut nos ista credamus. Semel enim Christus mortuus est pro peccatis nostris'. 
It is of crucial importance, too, that Augustine sees this last period of the world as one of an indefinite duration. Such a view frees from any speculation regarding the end of the world and the signs that might indicate this end. Augustine repeatedly and emphatically remarks that the end of the world, and its signs, are not to be defined by humans (e.g. DCD XVIII, 53-54; cf. En in Ps. 40, 1). He refers to the fact that in the Gospel of Matthew no number of generations is given to indicate the final age of the world (e.g. De Gen. c. Man. I, 4 [Mt 1; cf. Mt 24:36]; see also DCD XXII, 30 [cf. Ac 1:7]). Furthermore, he refers to not only Acts 1:7, but also Matthew 24:36 and I Thessalonians 5:2 (e.g. En. in Ps. 6, 1). And, especially against the chiliasts, he also considers the number 1000 to be a 'perfect' or 'complete number' (numerus perfectus), because it pertains not to an exact but to a round number, that is to a period of indefinite length.

Neither the world's crises, nor its sometimes shocking changes and transformations, are definitive indicators of whether or not the end of time has arrived. It is for this reason that Augustine could assess the shocking events of the fall of Rome in 410 in a wholly different way (cf. Van Oort 1991:57-62; Gärtner 1998:160-179). To be sure, he did not feel himself unaffected by the events of his time, but he was never shaken in his fundamental Christian outlook. We find the same line of thinking beautifully attested in his correspondence with a certain bishop Hesychius in Dalmatia (Epp. 197-199; BA 37, 763-765).

It is from this correspondance with Hesychius that we may learn exactly how Augustine did in fact see certain signs as indicators of the last phase of world history. In these letters Augustine again states that the 'last days' started with the time of the apostles and will end with the return of Christ. All these certain facts are based on the historia sacra. Apart from these facts, however, there are other important indications: Christ Himself said that the gospel should first be proclaimed to all peoples (Mt 24: 3 ff.; Mk 13 and Lk 21); in the last days nation shall rise up against nation; there will be plagues, famines, earthquakes; wickedness will increase and love will wax cold. Sometimes it seems that it is already at this point ... (esp. s. 38, 8). What Augustine wrote to the bishop of Salona (a city near modern-day Split in Dalmatia, Croatia) at the end of 418 or the beginning of 419 , he would repeat in 426 , and in book XX of The City of God there is an explicit reference to his analysis in the letter De fine saeculi to Hesychius (see DCD XX, 5).

\section{The events of the end times}

Thus, in regard to the events of the end times in the more usual sense ('the last hour', 'the last day', 'the last times'), Augustine did have something to say. Once the Lutheran theologian Hans Eger (1933) authored a book in which he brought together all data available to him. Eger's 'Gesamtschau' of Augustine's occasional and dispersed remarks on eschatology, however, does resemble more a dogmatical locus on eschatology than the real and authentic Augustine. The church father himself never wrote in a systematic-dogmatic way on the 'intermediate state' after bodily death, purgatory, parousia, resurrection, the final judgement, the punishments of hell or the rewards of heaven. Any scholastic systematisation in these matters is commonplace rather than authentic (cf. Eger 1933:24). This does not mean, however, that the summarising study of Eger is of no value. On the contrary, as far as I am aware, it remains the most comprehensive overview available to us (see also Daley 1991:131-150; Scanlon 1999:316-318).

When I discuss here certain statements by Augustine regarding 'the last days', it is with the explicit annotation that they must be heard in the context of his overall concept of history, time, and the future. Augustine's most important and, evidently, most systematic reflections we find in book XX of The City of God. Here, he explicitly remarks that 'the last day' (ultimus dies), that is 'the end time' (novissimus tempus) in sensu stricto, will arrive with Christ's return (DCD XX, 1). ${ }^{17}$ In accordance with his being a theologian of the historia sacra, Augustine emphasises that his testimonies will be limited to the witnesses he finds in the books of the New and Old Testaments. ${ }^{18}$ He deals with these testimonia in a more or less orderly succession and, evidently, in an extensive manner. Concerning the last mentioned characteristic of his discussion one may note that, in the meantime, the bishop has reached the age of seventy two, and appears to be aware of his own loquacitas senectutis (cf. s. 355, 7). Besides, it may be stressed that he always dictated his works to stenographers (Hagendahl 1971:24-38, esp. 31) and, moreover, only managed to do so during his spare time (i.e. often during the evenings and nights) when his many episcopal duties did not deter him. All these factors have a certain bearing on his extensive and more or less meandering exposition of 'eschatology'.

Outlining Augustine's exposition in a summary, one may remark the following. First of all, it is essential to him that Christ, 'the first and eternal, whose hand founded the earth and whose right hand established the heavens' (cf. Isa 48:13), encompasses all times. It is through Him that all world time is directed towards a final goal. Just as the Creation was a cosmic event through Him, so also is its regeneration. Hence, Christ creates a new world after the old one is destroyed by a global fire. In the regenerated world, the New Jerusalem will descend and the earthly part of the City of God will be added to her. Thus, the part of the civitas Dei subjected to time and corruptibility will be exalted to timeless incorruptibility as well.

Before these things happen, however, there will be a last trial of the part of the civitas Dei now sojourning in the world. This last trial of the City of God's earthly part will function as its purification. One final battle must be fought with Satan,

17.'Quod ergo in confessione ac professione tenet omnis ecclesia dei veri Christum de caelo esse venturum ad vivos ac mortuos iudicandos, hunc divini iudicii ultimum diem dicimus, id est novissiumum tempus'.

18.In this order: 'The old testimonia proclaim the new ones' (cf. $D C D X X, 4$ ). The same order is also explicitly mentioned in the Breviculus of $D C D X X, 4$ : 'Quod ad disserendum de novissimo iudicio Dei novi primum testamenti ac deinde veteris disserendum de novissimo iudicio Dei novi primum testamenti ac deinde veteris
testimonia prolaturus sit'. In all probability the ancient breviculus or summary of testimonia prolaturus sit'. In all probability the ancient breviculus or summary
the contents of $D C D$ is authored by A. himself (see e.g. Marrou 1976:253-265). 
who will be let loose at the end of time ( $D C D X X, 11)$. An abundant increase in wickedness will be a characteristic feature of the end times. From the Apocalypse of John, Augustine also takes the view that Satan will be incarnated in the Antichrist. This Antichrist will be a real personality acting in history. According to Augustine, one can already know the real existence and character of the Antichrist: just as Christ was typified in the prophets and patriarchs of the Old Testament, so Satan has his predecessors in the many ungodly powers ( $D C D X X, 19)$. Everything that pagan persecutors, heretics and fake Christians wrought against the church is recapitulated in this figure. In the last days the persecutions dealt on the primitive church will recur with unprecedented ferocity. The last persecution and battle will be universal, directed against the worldwide ecclesia. Gog and Magog (Rv 20:9) should, therefore, not be equated with the barbaric (that is, Germanic) tribes now invading the Roman Empire, as the followers of the Antichrist will come from all nations ( $D C D X X, 11)$. The 'mystery of iniquity' (2 Th 2:7) is difficult to explain. For Paul it was probably not the Roman Empire of Nero, ${ }^{19}$ but the mysterium iniquitatis might point to 'the wicked and the hypocrites who are now in the church, waiting until they have reached a number so great as to provide the Antichrist with many followers' ( $D C D$ $X X, 19) .{ }^{20}$ However that may be, God allows the display of Satan's power in order to test and purify the true believers. They will emerge fully purified after the last persecution is ended by Christ's annihilation of the Antichrist (DCD XX,12). In the last times the conversion of the Jews will take place: they were the first nation called to be citizens of the City of God, but did not acknowledge 'our Christ'. Nevertheless, in the end times Elijah (Ml 4:5-6) will come and teach them the spiritual meaning of the Law (exponendo legem spiritaliter), just as the prophets had also understood the Law in a spiritual manner. ${ }^{21}$

The previous lines may provide an adequate summary of Augustine's substantial amount of words on the end times. His extensive exposé is in fact an exegetical mosaic in which 'new and old things' (cf. Mt 13:52 in DCD XX, 4) are brought to the fore, whereas a main argument is rather difficult to detect. In the conclusion of book $X X$ he himself gives the following summary, written in rhythmical Latin, and sounding like a series of credal texts:

The events we learnt that will happen at or in connection with that judgment are the following: Elias the Thesbite will come. The

19. Both Jerome and A. rejected the widespread notion of a Nero redivivus.

20.'Alii vero et quod ait: Quid detineat scitis et mysterium operari iniquitatis non putant dictum nisi de malis et fictis, qui sunt in ecclesia, donec perveniant ad tantum numerum, qui Antichristo magnum populum faciat'. Also in ep. 199,139 A. remarks that the false Christians, under the influence of the wonders and signs of the Antichrist, would leave the community of Christ (i.e. the true church) in the end times.

21.The Septuagint text of Malachi 4:5-6 ('the heart of the father will be turned to the son') allows, according to $\mathrm{A}$. in $D C D X X, 29$, an even better explanation, though with the same result: 'In the words of the Seventy, whose translation has a prophetic character, one may find another, even better meaning. One can understand it as such: that Elijah will turn the heart of the Father to the Son, without inducing that the Father loves the Son, but to show the love of the Father for the Son and to the Father loves the Son, but to show the love of the Father for the Son and to
thereby the Jews to love the one who they previously hated, namely the thereby move the Jews to love the one who they previously hated, namely the from our Christ. Because they have this idea, the heart of God would thus turn to the Son, when they themselves with converted hearts will know the love of the the Son, when they themselves with converted hearts will know the love of the
Father for the Son'. A.'s opinions regarding the Jews were very important (because Father for the Son'. A.'s opinions regarding the Jews were
they were very influential) (Van Oort 2008:782-792).
Jews will believe. The Antichrist will persecute the church. Christ will come to speak judgment. The dead will rise. The good and the wicked will be separated. The world will be burnt and regenerated. We should believe that all this will happen, but how and in what order, human understanding cannot perfectly teach us, but only the experience of the events themselves. I am of the opinion, however, that they will happen in the sequence in which I have called them to mind. (DCD XX, 30 $)^{22}$

\section{Augustine and Chiliasm}

A final aspect of Augustine's discussion of the end times deserves special attention. We consider it concisely, as Augustine himself also spoke about it (comparatively) briefly (esp. DCD XX, 6-9; see e.g. Folliet 1956:371-390; Lohse 1967:221-240; see also Scholz 1911:109-121).

In actual fact, Augustine's view, that the end times had already started with the advent of Christ leaves no room for any chiliastic ideas. He understands the present as being the time of the fulfilment, because between the end of time and Christ's return there is no new period, such as the chiliasts taught (see Blum 1981:729-733). ${ }^{23}$ When he was a presbyter, Augustine did lean towards chiliastic ideas, ${ }^{24}$ but, especially in book XX of The City of God, he rejects such notions. The first resurrection (prima resurrectio; cf. Apoc 20,5-6) is, according to chiliastic views, the start of a new earthly kingdom in which Christ will reign with the Christian believers.

According to Augustine, what is meant is the spiritual resurrection of the people freed by Christ from what he terms 'the first death' (prima mors). In Christ the spiritual resurrection of believers has already started. That first resurrection is necessary for believers to have a part in. The second is the bodily resurrection which will take place after the final judgement. In the same vein Augustine also interprets the statements in the Apocalypse of John, that Satan would stay bound for a thousand years. This round number (numerus perfectus) points to a definite period wherein the spiritual resurrection (i.e. the resurrection of the souls, resurrectio animarum) removes the believers from Satan's rule and incorporates them in the church. How long the period will last, we humans do not know. Neither do we

22.II illo itaque iudicio vel circa illud iudicium has res didicimus esse venturas. Helian Thesbiten, fidem ludaeorum, Antichristum persecuturum, Christum iudicaturum, mortuorum resurrectionem, bonorum malorumque diremptionem, mund conflagrationem elusdemque renovationem. Quae omnia quidem ventura esse credendum est; sed quibus modis et quo ordine veniant, magis tunc docebit rerum experientia, quam nunc ad perfectum hominum intellegentia valet consequi.
Existimo tamen eo quo a me commemorata sunt ordine esse ventura'.

23.Examples of Chiliasts in one form or another (e.g. as 'pre-millennialists') are Papias, Justin, Irenaeus, Tertullian, Hippolytus, Commodianus, and Lactantius. The works of Origen brought an end to all chiliastic theories in the East. By A.'s authority millennialism disappeared from the official dogma of the Christian church in the West. That (also) Tyconius' Commentarium in Apocalypsin served as a source for A. (thus the opinion of Scholz 1911:114-121, and many researchers in his wake), is not evidenced by the present state of the textual tradition of Tyconius' Commentarium (cf. Van Oort 1991:263-272).

24.In or about the year 393. Evidence for his temporary chiliastic view is $s .259,2$, where A. says: 'Septimus [sc. dies] quietem futuram sanctorum in terra. Regnabit enim Dominus in terra cum sanctis suis, sicut dicunt Scripturae.... It must be remarked that, as a 'chiliast', A. still focused on 'spiritual pleasures' (deliciae spirituales); cf. DCD XX, 7, where he alludes to his earlier 'chiliastic' period: 'etiam nos hoc opinati fuimus aliquando'. A. never adhered to any materialistic chiliasm, however; in his opinion this form of chiliasm is 'ridiculous' (XX,7: quaedam ridiculae fabulae), 'excessive' and 'incredible' ( $X X, 7$ : non solum nullam modestiam ridiculae fabulae), 'excessive' and 'incredible' ( $X X, 7$ : non solum nullam modestiam
tenent, sed modum quoque ipsius incredulitatis excedunt), even 'shameless' (XX, 17: impudentiae nimiae mihi videtur). 
need to know, because the millennium is not a future which we should look forward to with fear and trembling, but it is a present lived by faith (see DCD XX, 9).

\section{Conclusions}

At the end of our analysis we may conclude by summarising the most important results:

- Augustine is no historian in the usual sense of the word. His idea of history, the present, the future, and the end times should therefore be evaluated within his wider theological-philosophical framework.

- His concept of historia sacra is the heuristic foundation for Augustine's idea of history.

- The present is not to be described in the terms of historia sacra. This opinion implies great carefulness (even principal reserve) in any pointing out of 'God's hand in history'.

- The end times have already started with the advent of Jesus Christ.

- In a salvation history perspective Jesus Christ's advent is an eschatological novum, because of its uniqueness it runs counter to any cyclical worldview.

- Any exact fixation of the end time's end (ultimus dies; novissimus tempus) is humanly impossible. ${ }^{25}$ Yet, from the perspective of historia sacra, there are important signs regarding the end times.

- Augustine's view on the present as the end time leaves, in principle, no room for any chiliastic expectations.

\section{Acknowledgements Competing interests}

The author declares that he has no financial or personal relationship(s) which may have inappropriately influenced him in writing this article.

\section{References}

Altaner, B., 1967, 'Die Bibliothek Augustins', in Kleine Patristische Schriften, pp. 174-180, Akademie Verlag, Berlin.

Berger, H., 1955, Calvins Geschichtsauffassung, Zwingli-Verlag, Zürich.

Blum, G.G., 1981, 'Chiliasmus II: Alte Kirche', Theologische Realenzyklopedie 7, 729-733.

Clarke, T.E., 1958, 'St. Augustine and Cosmic Redemption', Theological Studies 19, 133-164.

Cullmann, O., 1965, Heil als Geschichte, Mohr, Tübingen.

Cullmann, O., 1946, Christus und die Zeit, Zollikon Verlag, Zürich.

Daley, B.E., 1991, The Hope of the Early Church: A Handbook of Patristic Eschatology, Cambridge University Press, Cambridge.

Eger, H., 1933, Die Eschatologie Augustins, Universitätsverlag, Greifswald.

Folliet, G., 1956, 'La typologie du sabbat chez saint Augustin. Son interprétation millénariste entre 389 et 400', Revue des Études Augustiniennes 2, 371-390.

Gärtner, H.A., 1998, 'Der Fall Roms. Literarische Verarbeitung bei Heiden und Christen', in J. van Oort \& D.Wyrwa (Hrsg.), Heiden und Christen im 5. Jahrhundert pp. 160-179, Peeters, Leuven.

25.It is important to note that this cognitive impossibility did not cause any moral defeatism for A. On the contrary: 'Let us live well and the times are good. We are the times: such as we are, so are the times'. See s. 80,8 , a sermon from c. 410 'Bene vivamus et bona sunt tempora. Nos sumus tempora; quales sumus, talia sunt tempora.'
Hagendahl, H., 1971, 'Die Bedeutung der Stenographie für die spätlateinische Literatur', Jahrbuch für Antike und Christentum 14, 24-38.

Hagendahl, H., 1967, Augustine and the Latin Classics, Almqvist \& Wiksell, Göteborg.

Horn, C., 1997, 'Geschichtsdarstellung, Geschichtsphilosophie und Geschichtsbewußtsein', in C. Horn (Hrsg.), Augustinus (n. 5), De civitate Dei, pp. 179-181, Akademie Verlag, Berlin. http://dx.doi.org/10.1524/9783050050409

Kamlah, W., 1951, Christentum und Geschichtlichkeit: Untersuchungen zur Entstehung des Christentums und zu Augustin's 'Bürgerschaft Gottes', Kohlhammer, StuttgartKöln.

Kamlah, W., 1940, Christentum und Selbstbehauptung: Historische und philosophische Untersuchungen zur Entstehung des Christentums und zu Augustin's 'Bürgerschaft Gottes', Klostermann, Frankfurt am Main.

Lancel, S., 1992, 'Breviculus conlationis cum Donatistis', in Augustinus-Lexikon 1, Fasc. 5/6., pp. 681-684, Schwabe, Basel.

Lohse, B., 1967, 'Zur Eschatologie des älteren Augustin (De Civ. Dei 20,9)', Vigiliae Christianae 21, 221-240. http://dx.doi.org/10.2307/1582079

Löwith, K., 1949, Meaning in History, University of Chicago Press, Chicago, IL.

Markus, R.A., 1970, Saeculum: History and Society in the Theology of St Augustine, Cambridge University Press, Cambridge.

Marrou, H-I., 1976, 'La division en chapitres des livres de La Cité de Dieu' in Patristique et Humanisme, pp. 253-265, Le Seuil, Paris.

Marrou, H-I., 1954-55, 'Saint Augustin et la légende de l'ange', in Bulletin de la Société Nationale des Antiquaires de France, pp. 131-135, Société Nationale des Antiquaires de France, Paris.

Marrou, H-I., 1950, L'ambivalence du temps de l'histoire chez saint Augustin, Institut des Études médievales, Montreal, J. Vrin, Paris.

Meijering, E.P., 1979, Augustin über Schöpfung, Ewigkeit und Zeit, E.J. Brill, Leiden.

Monceaux, P., 1923, Histoire littéraire de l'Afrique chrétienne, VII, É. Leroux, Paris.

Müller, C., 1993, Geschichtsbewußtsein bei Augustinus: Ontologische, anthropologische und universalgeschichtlich/heilsgeschichtliche Elemente einer augustinischen 'Geschichtstheorie', Augustinus Verlag, Würzburg.

Noth, M., 1991, The Deuteronomistic History, JSOT Press, Sheffield.

O'Daly, G., 1999, Augustine's City of God: A Reader's Guide, Clarendon Press, Oxford.

O'Daly, G.J.P., 1986, 'Aeternitas', in Augustinus-Lexikon, 1, Fasc. 1/2, pp. 159-164, Schwabe, Basel.

O'Daly, G.J.P., 1977, 'Time as Distentio and St. Augustine's Exegesis of Philippians 3, 12-14', Revue des Études Augustiniennes 23, 265-271.

Perler, O., 1969, Les voyages de saint Augustin, Études Augustiniennes, Paris.

Quinn, J.M., 1999, 'Time', in A.D. Fitzgerald (ed.), Augustine through the Ages: An Encyclopedia, pp. 832-838, Eerdmans, Grand Rapids, MI.

Scanlon, M.J., 1999, 'Eschatology', in A.D. Fitzgerald (ed.), Augustine through the Ages: An Encyclopedia, pp. 316-318, Eerdmans, Grand Rapids, MI.

Schmidt, E.A., 1985, Zeit und Geschichte bei Augustin, Heidelberger Akademie der Wissenschaften, Heidelberg.

Scholz, H., 1911, Glaube und Unglaube in der Weltgeschichte: Ein Kommentar zu Augustins De civitate Dei, Hinrichs, Leipzig. (repr. 1967, Zentral-Antiquariat der DDR, Leipzig).

Schwarte, K-H., 1966, Die Vorgeschichte der augustinischen Weltalterlehre, Habelt, Bonn.

Smits, L., 1956-58, Saint Augustin dans l'œuvre de Jean Calvin, I-II, Van Gorcum, Assen.

Stählin, G., 1933, Theologisches Wörterbuch zum Neuen Testament, I. Kohlhammer, Stuttgart.

Trompf, G.W., 2000, Early Christian Historiography, Continuum, London, New York, NY.

Van Oort, J., 2008, 'ludaei' in Augustinus-Lexikon, 3, Fasc. 5/6, pp. 782-792, Schwabe, Basel.

Van Oort, J., 1991, Jerusalem and Babylon. A Study into Augustine's City of God and the Sources of his Doctrine of the Two Cities, E.J. Brill, Leiden, New York, København, Köln.

Von Rad, G., 1974, 'Das Wort Gottes und die Geschichte im Alten Testament', in Gottes Wirken in Israel: Vorträge zum Alten Testament, pp. 191-212, Neukirchener Verlag, Neukirchen-Vluyn.

Von Rad, G., 1974, 'Theologische Geschichtsschreibung im Alten Testament', in Gottes Wirken in Israel: Vorträge zum Alten Testament, pp. 175-190, Neukirchener Verlag, Neukirchen-Vluyn.

Von Rad, G., 1958, 'Die deuteronomistische Geschichtstheologie in den Königsbüchern', in Gesammelte Studien zum Alten Testament, pp. 189-204, Kaiser Verlag, München.

Wachtel, A., 1960, Beiträge zur Geschichtstheologie des Aurelius Augustinus, L. Rörscheid, Bonn.

Weidmann, C., 1998, Augustinus und das Maximianistenkonzil von Cebarsussi: Zur historischen und textgeschichtlichen Bedeutung von Enarratio in Psalmum 36, 2 18-23, Verlag der Österreichische Akademie der Wissenschaften, Wien.

Williams, R., 1999, 'Creation', in A.D. Fitzgerald (ed.), Augustine through the Ages: An Encyclopedia, pp. 251-254, Eerdmans, Grand Rapids, MI. 